\title{
COMPARATIVE ANALYSIS OF PLANTAIN AND BANANA MARKETING IN PORT HARCOURT CITY METROPOLIS, RIVERS STATE, NIGERIA
}

\author{
Sunday King Agbagwa ${ }^{1}$, Ikechi Kelechi Agbugba ${ }^{1,2}$, Phokele Maponya ${ }^{3 凶}$ \\ ${ }^{1}$ Rivers State University, Nigeria \\ ${ }^{2}$ Rome Business School, Nigeria \\ ${ }^{3}$ Agricultural Research Council, South Africa
}

\begin{abstract}
The study was centred on the comparative analysis of plantain and banana marketing in the Port Harcourt Metropolis, Rivers State, Nigeria. A structured questionnaire was used to collect data from 126 plantain and banana marketers whom were selected using a simple random sampling technique from seven purposively-selected markets in the study area. The data were analysed using descriptive statistics, a gross margin model, and the t-test. The findings showed that plantain and banana marketers were $100 \%$ female, that is only females were identified in the trade; $51.6 \%$ and $56.3 \%$ of these plantain and banana marketers had mean ages of 40.8 years and 59.5 years respectively; in addition, the majority of the marketers were married ( $73.0 \%$ and $65.1 \%$ respectively). Furthermore, they earned a monthly profit of $\$ 55,370.42$ and $\$ 47,654.74$ respectively, which indicates that both businesses are profitable. Further, the plantain and banana trade shared similar marketing channels, the number of which was four, with the most dominant channel being the one composed of the producer, rural assembler, wholesaler, retailer, and the consumer. The t-test analysis demonstrated that the difference in profit by plantain and banana marketers was statistically significant at the $p$-value of $<0.05$. Unemployed youths in Rivers State should be trained by well-meaning organisations so that they can take up the marketing of plantains/bananas as a means of earning a living due to their profitability.
\end{abstract}

Keywords: plantains, bananas, marketing, Port Harcourt metropolis

\section{INTRODUCTION}

In Nigeria and other developing countries alike, plantains and bananas are considered staple food crops for many, so it is not surprising why Nigeria is regarded as one of the largest plantain and banana producing nations across the globe (Kainga and Seiyabo, 2012).

In Nigeria, plantains and bananas are valuable tree crops because of their economic importance and role in health and nutrition (Nwaiwu et al., 2012). Nutritionally, ripe plantains and bananas are a good source of energy, while unripe plantains and bananas are sources of iron (Achike et al., 2011). This perhaps explains why plantains and bananas are appreciated in Nigerian homes and families. These crops serve as sources of employment and cash income to rural dwellers in countries like Nigeria. They have become crucial revenue earners as they are equally exported just as they are traded within the region (Olumba and Onunka, 2020). Furthermore, the economic importance of plantains and bananas makes them invaluable tree crops in countries such as Nigeria where health, nutrition, and dietary implications of foods are of top priority in most intellectual discourse (Nwaiwu et al., 2012).

Marketing has a guiding and stimulating impact, with plantain and banana marketing being one of the driving forces for the economic development of rural

$\bowtie$ Phokele Maponya, Agricultural Research Council, South Africa, e-mail: maponyap@arc.agric.za, https://orcid.org/0000-00034883-2474 
areas (Obetta et al., 2018). Marketing of food and agricultural commodities such as bananas and plantains covers every step to be carried out between the producer and consumer, including processing, storage, assembling, wholesaling, and retailing (Taleke, 2010; Agbugba, 2020).

The EPAR (2013) and Oladapo et al. (2007) observed that the production and consumption of plantains and bananas are increasing and the link between producers and consumers is the market in which these commodities are sold. With this in mind, it becomes crucial to examine the marketing of these commodities, because marketers will always serve as a bridge between the producer and consumer. A study on the marketing of these commodities becomes ever more important as bananas and plantains have a short shelf-life and if not sufficiently marketed the producer can suffer losses (EPAR, 2013; Eronmwon et al., 2014). Therefore, the objectives of this study are as follows:

i. describe the socio-economic characteristics of marketers;

ii. estimate the profitability of plantain and banana marketing, and;

iii. describe the marketing channels of these commodities.

\section{Study hypothesis}

HO: There is no significant difference between profit levels in plantain marketing and banana marketing.

\section{MATERIALS AND METHODS}

The study was conducted in the Port Harcourt Metropolis, Rivers State, Nigeria. The study area comprises the city of Port Harcourt and Obio/Akpor Local Government Areas, which are core areas of the Port Harcourt Metropolis. The city of Port Harcourt is the administrative capital of Rivers State and the centre of business activities in the Niger Delta region of Nigeria. The territory is located at the latitude of $4.75^{\circ} \mathrm{N}$ and the longitude of $7{ }^{\circ} \mathrm{E}$ in Rivers State, Port Harcourt Master Plan (1975). It is an urban area which lies along the Bonny River and is located in the Niger Delta area with an estimated population of $1,865,000$ people (NPC, 2010).

A two-stage sampling technique was used for this study. The first stage involved the purposive selection of seven markets. This selection was dictated by the fact that these markets serve as major markets in the metropolis, with plantain banana sales being significant in them and the volume of trade across them being similar. The markets were the Rumu Wogi Mile One Market, Oruwuoroko Nkpolu Mile Three Market, Creek Road Market, Eligbolo Market, Okra Market, Rumuodumaya Market, and Oilmill Market. The second stage involved the simple random sampling of 18 marketers (18 marketers were considered fair representation based on the information provided by informal market associations of plantain and banana marketers across the markets) from the seven markets each, who responded to a questionnaire and took part in an oral interview. As a result, the sample size included 126 respondents for the plantain market and banana market each.

In an attempt to analyse the data obtained, frequencies, percentages, and the mean were used to achieve objectives (i) and (iii), i.e. the description of the socioeconomic characteristics of the marketers and the marketing channels of the commodities. In the case of objective (ii), which was to estimate the profitability of plantain and banana marketing, a gross margin model was applied.

\section{Gross margin analysis}

A gross margin model served as a pathway in which the profitability of plantain and banana marketing was estimated. The model is specified as follows:

$$
\mathrm{GM}=\mathrm{TR}-\mathrm{TVC}
$$

where:

GM - gross margin, TR - total revenue, TVC - total variable cost, TFC - total fixed cost, $\pi$ (profit) $-\mathrm{GM}-\mathrm{TFC}$.

\section{Test of the hypothesis}

The hypothesis stating that there is no significant difference between profit levels in plantain marketing and banana marketing was tested using the t-test. This test was used because it was assumed that the two independent samples drawn from the populations had unequal variances, and can be calculated as follows:

$$
t=\frac{\bar{x}_{1}-\bar{x}_{2}}{\sqrt{\frac{s_{1}^{2}}{n_{1}}+\frac{s_{2}^{2}}{n_{2}}}}
$$

where:

$\bar{x}_{1}-$ mean of the first sample, $\bar{x}_{2}-$ mean of the second sample, $n_{1}$ - sample size (i.e. number of observations) 
of the first group, $n_{2}-$ sample size (i.e. number of observations) of the second group, $s^{2}$ - standard deviation in the first group, $s_{2}{ }_{2}-$ standard deviation in the second group.

For significance testing, the degree of freedom was $2 n-2$, where $n$ is the number of participants in each group.

\section{RESULTS AND DISCUSSION}

\section{Socio-economic characteristics of the respondents}

The results presented in Table 1 and Table 2 reveal that $100 \%$ of the marketers of plantains and bananas were female, with no male marketers whatsoever. These findings are consistent with study by Akinyemi et al. (2017), where they argued that females dominated the marketing of plantains/bananas in Oyo State, Nigeria. This argument is supported by Mayokun and Fisayo (2010), who stressed that about $80 \%$ of all commercial activities concerning food commodities in Nigeria are facilitated by women.

In addition, Table 4.1 indicates that the mean age of the plantain marketers was 40.8 years, whereas that of the banana marketers stood at 59.5 years. This indicates that while the majority of the plantain marketers were still in their active age, their banana counterparts were not. Olasunkanmi et al. (2012) mentioned that individuals who are in their active ages have the tendency to be more productive. The result concerning the plantain marketers is in line with the findings by Agbugba et al. (2020), who evaluated the socio-economic and profitability analysis of honey marketing in the Port Harcourt city local government area of Rivers State, Nigeria, in which youths were identified as a key custodian of honey marketing in the study area.

Furthermore, the results presented in Table 1 and Table 2 indicate that $73.0 \%$ and $65.1 \%$ of the plantain and banana marketers, constituting the majority, were married respectively. This finding supports the investigation by Aina et al. (2012), who argued that $86.7 \%$ of plantain marketers in the Odigbo Local Government Area of Ondo State were married. The marital status of the marketers has a massive effect because it is reflected in their socio-economic obligation to their families.

Table 1 shows that $49.2 \%$ had $6-10$ years marketing experience, followed by $16.7 \%$ and $19.8 \%$ of the respondents who had 1-5 years and 11-15 years of
Table 1. Socio-economic characteristics of the plantain marketers $(n=126)$

\begin{tabular}{|c|c|c|c|}
\hline Characteristics & Frequency & Percentage & Mean (years) \\
\hline \multicolumn{4}{|l|}{ Gender } \\
\hline Male & 0.0 & 0.0 & \\
\hline Female & 126 & 100.0 & \\
\hline Total & 126 & 100.0 & \\
\hline \multicolumn{4}{|l|}{ Age (years) } \\
\hline $19-29$ & 6 & 4.8 & \\
\hline $30-39$ & 65 & 51.6 & \\
\hline $40-49$ & 24 & 19.0 & 40.8 \\
\hline$>49$ & 31 & 24.6 & \\
\hline Total & 126 & 100.0 & \\
\hline \multicolumn{4}{|l|}{ Marital status } \\
\hline Single & 5 & 4.0 & \\
\hline Married & 92 & 73.0 & \\
\hline Widowed & 29 & 23.0 & \\
\hline Total & 126 & 100.0 & \\
\hline \multicolumn{4}{|c|}{$\begin{array}{l}\text { Marketing experience } \\
\text { (years) }\end{array}$} \\
\hline $1-5$ & 21 & 16.7 & \\
\hline $6-10$ & 62 & 49.2 & \\
\hline $11-15$ & 25 & 19.8 & 9.6 \\
\hline$>15$ & 18 & 14.3 & \\
\hline Total & 126 & 100.0 & \\
\hline
\end{tabular}

Source: field survey, 2020.

marketing experience respectively. Sadiq et al. (2015) emphasised that years of experience improves risk management in businesses. However, Table 2 reveals that unlike the plantain marketers, the majority (44.4\%) of the banana marketers had 11-15 years of marketing experience; long years of marketing experience is crucial, leading to forecasting possible challenges and likely solutions possibly translating into a higher profit in the business (Ben-Chendo et al., 2013). 
Agbagwa, S. K., Agbugba, I. K., Maponya, P. (2021). Comparative analysis of plantain and banana marketing in Port Harcourt city metropolis, Rivers State, Nigeria. J. Agribus. Rural Dev., 2(60), 161-167. http://dx.doi.org/10.17306/J.JARD.2021.01404

Table 2. Socio-economic characteristics of the banana marketers $(n=126)$

\begin{tabular}{|c|c|c|c|}
\hline Characteristics & Frequency & Percentage & Mean (years) \\
\hline \multicolumn{4}{|l|}{ Gender } \\
\hline Male & 0 & 0.0 & \\
\hline Female & 126 & 100.0 & \\
\hline Total & 126 & 100.0 & \\
\hline \multicolumn{4}{|l|}{ Age (years) } \\
\hline $19-29$ & 13 & 4.8 & \\
\hline $30-39$ & 82 & 21.4 & \\
\hline $40-49$ & 71 & 56.3 & 59.5 \\
\hline$>49$ & 22 & 17.6 & \\
\hline Total & 126 & 100.0 & \\
\hline \multicolumn{4}{|l|}{ Marital status } \\
\hline Single & 13 & 10.3 & \\
\hline Married & 82 & 65.1 & \\
\hline Widowed & 31 & 24.6 & \\
\hline Total & 126 & 100.0 & \\
\hline \multicolumn{4}{|l|}{$\begin{array}{l}\text { Marketing experi- } \\
\text { ence (years) }\end{array}$} \\
\hline $1-5$ & 6 & 4.8 & \\
\hline $6-10$ & 40 & 31.7 & \\
\hline $11-15$ & 56 & 44.4 & 11.9 \\
\hline$>15$ & 24 & 19.0 & \\
\hline Total & 126 & 100.0 & \\
\hline
\end{tabular}

Source: field survey, 2020.

\section{Average monthly costs/returns on plantain and banana marketing}

According to Table 3 and Table 4, while the plantain marketers earned an average monthly total revenue of N229,495.2 (603.95 USD), that for banana marketers stood at 191,222.2 (503.23 USD), which is quite lower than that of their plantain counterparts. What is more, the plantain and banana marketers recorded an average monthly total cost (composed of the average monthly total variable cost and the total fixed cost) of $174,124.78$ (457.62 USD) and $\$ 143,567.46$ (377.31 USD) respectively. These values accounted for the average monthly
Table 3. Average monthly costs/returns on plantain marketing

\begin{tabular}{lr}
\hline \multicolumn{1}{c}{ Item } & Amount (N) \\
\hline Total revenue (TR) & $229,495.2$ \\
Cost of plantain & $155,746.8$ \\
Transport expenses & $11,285.71$ \\
Tax/levy & $2,127.78$ \\
Loading/offloading & $2,355.56$ \\
Total variable cost (TVC) & $171,515.85$ \\
Gross margin (GM) & $57,979.35$ \\
Depreciation & 196.23 \\
Rent/month & $2,412.70$ \\
Total fixed cost (TFC) & $2,608.93$ \\
Total cost (TC) & $174,124.78$ \\
Profit & $55,370.42$ \\
Net return on investment (NROI) & 1.32 \\
\hline
\end{tabular}

$\mathrm{NROI}=\mathrm{TR} / \mathrm{TC}$

Average cost of plantains/bunch $=1530.16$ (4.02 USD); Selling price $=\$ 2269.84$ (5.97 USD)

Source: field data analysis, 2019.

Table 4. Average monthly costs/returns on banana marketing

\begin{tabular}{lr}
\hline \multicolumn{1}{c}{ Item } & Amount (N) \\
\hline Total revenue (TR) & $191,222.2$ \\
Cost of bananas & $128,549.2$ \\
Transport expenses & $8,686.51$ \\
Tax/levy & $1,950.79$ \\
Loading/offloading & $1,856.35$ \\
Total variable cost (TVC) & $141,042.85$ \\
Gross margin (GM) & $50,179.35$ \\
Depreciation & 173.02 \\
Rent/month & $2,351.59$ \\
Total fixed cost (TFC) & $2,524.61$ \\
Total cost (TC) & $143,567.46$ \\
Profit & $47,654.74$ \\
Net return on investment (NROI) & 1.33 \\
\hline
\end{tabular}

$\mathrm{NROI}=\mathrm{TR} / \mathrm{TC}$

Average cost of bananas/bunch $=\$ 1,810.32$ (4.76 USD); Selling price $=\$ 2,695.24$ (7.08 USD)

Source: field data analysis, 2019. 
gross margin of $\$ 57,979.35$ (152.38 USD) for the plantain marketers and $\$ 50,179.35$ (131.88 USD) for the banana marketers.

As a result, the estimated average monthly profit to be obtained by both the plantain marketers and banana marketers stood at $\$ 55,370.42$ (145.52 USD) and $¥ 47,654.74$ (125.24 USD) respectively. This result is in line with the findings by Akinyemi et al. (2017) who examined the market structure and performance for plantains and bananas in southern Nigeria. The NROI featured in Table 3 and Table 4 has a value of 1.32 for the plantain marketers and 1.33 for the banana marketers, possibly implying that for every 1.00 invested into plantain or banana marketing in the study area, a return of 1.32 or $\$ 1.33$ was obtained respectively.

\section{Plantain and banana marketing channels}

Various channels associated with the marketing of plantains and bananas in the study area are presented in Table 5 and Table 6 respectively. These tables are additionally supported by a diagram given in Fig. 1 .

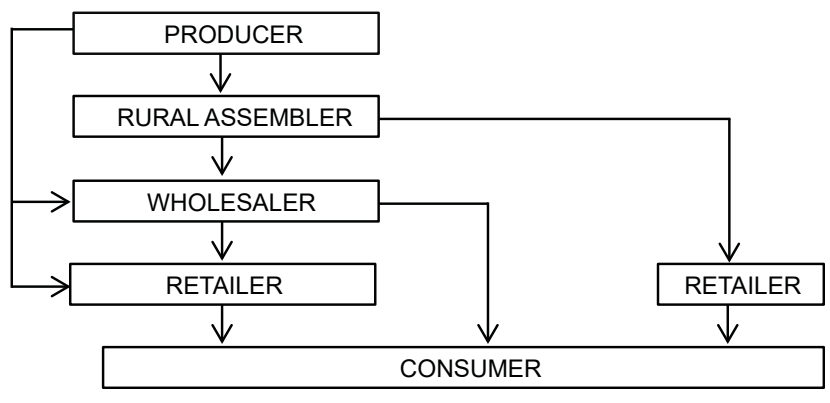

Fig. 1. Marketing channels of plantains and bananas in the Port Harcourt metropolis Source: field survey, 2020.

The analysis showed that the majority of plantain and banana traded in the markets were supplied from neighbouring states such as Abia, Bayelsa, and Cross River. Meanwhile, Table 5 and Table 6 reveal that both plantain marketing and banana marketing use similar four-tier marketing channels. This study finds that the most prevalent channel in the marketing of plantains

Table 5. Plantain marketing channels by percentage $(n=126)$

\begin{tabular}{lcc}
\hline \multicolumn{1}{c}{ Channels } & Score & Percentage (\%) \\
\hline Producer -> Rural Assembler $->$ Wholesaler $->$ Retailer $->$ Consumers & 87 & 33.5 \\
Producer -> Rural Assembler -> Wholesaler $->$ Consumers & 55 & 21.2 \\
Producer -> Wholesaler -> Consumers & 70 & 26.9 \\
Producer -> Retailer -> Consumers & 48 & 18.5 \\
Total & 260 & 100.0 \\
\hline
\end{tabular}

Source: field survey, 2020.

Table 6. Banana marketing channels by percentage $(n=126)$

\begin{tabular}{lcc}
\hline \multicolumn{1}{c}{ Channels } & Score & Percentage (\%) \\
\hline Producer -> Rural Assembler -> Wholesaler -> Retailer -> Consumers & 88 & 37.9 \\
Producer -> Rural Assembler -> Wholesaler -> Consumers & 51 & 22.0 \\
Producer -> Wholesaler -> Consumers & 62 & 26.7 \\
Producer -> Retailer -> Consumers & 31 & 13.4 \\
Total & 232 & 100.0 \\
\hline
\end{tabular}

Source: field survey, 2020. 
Table 7. T-test comparison of profit of the plantain and banana marketers

\begin{tabular}{|c|c|c|c|c|c|c|c|c|c|}
\hline \multirow{3}{*}{ Profit } & \multicolumn{2}{|c|}{$\begin{array}{l}\text { Levene's test } \\
\text { for equality } \\
\text { of variances }\end{array}$} & \multicolumn{7}{|c|}{ t-test for equality of means } \\
\hline & \multirow[t]{2}{*}{$\mathrm{F}$} & \multirow[t]{2}{*}{ Sig. } & \multirow[t]{2}{*}{$\mathrm{t}$} & \multirow[t]{2}{*}{ Df } & \multirow{2}{*}{$\begin{array}{l}\text { Sig. } \\
\text { (2-tailed) }\end{array}$} & \multirow{2}{*}{$\begin{array}{l}\text { Mean } \\
\text { difference }\end{array}$} & \multirow{2}{*}{$\begin{array}{l}\text { Std. error } \\
\text { difference }\end{array}$} & \multicolumn{2}{|c|}{$\begin{array}{l}95 \% \text { confidence interval } \\
\text { of the difference }\end{array}$} \\
\hline & & & & & & & & lower & upper \\
\hline $\begin{array}{l}\text { Equal variances } \\
\text { assumed }\end{array}$ & 6.398 & 0.012 & 3.649 & 250 & 0.000 & $7,715.67976$ & $2,114.24150$ & $3,551.68453$ & $1,1879.67500$ \\
\hline $\begin{array}{l}\text { Equal variances } \\
\text { not assumed }\end{array}$ & & & 3.649 & 231.564 & 0.000 & $7,715.67976$ & $2,114.24150$ & $3,550.07138$ & $11,881.28814$ \\
\hline
\end{tabular}

Significant for $\mathrm{P}<.05$, Not significant for $\mathrm{P}>.05$.

Source: own elaboration based on SPSS.

and bananas was the first channel, which includes the producer, rural assembler, wholesaler, retailer, and consumer, constituting $33.5 \%$ and $37.9 \%$ of the share in the total marketing channels respectively.

Looking from another perspective, Fig. 1 depicts that plantain and banana marketing channels in the study area are decentralised, meaning that both wholesalers and retailers purchase their products directly from producers. It is sometimes the case that wholesalers and retailers have to purchase from rural assemblers who move into farms to collect the products from farmers (the reason for this was that farms are numerous and scattered without access roads). The rural assembler aggregates these products to display them at a local market where prospective wholesalers and retailers can buy them.

\section{Test of the stated hypothesis}

The t-test was applied to compare the profits of the plantain marketers and banana marketers in the study area. The study rejected the null hypothesis on the grounds that the p-value of 0.000 presented in the "equal variances not assumed" row in Table 7 is less than 0.05 , pointing to a statistically significant difference in profit between the plantain and banana marketers. The "equal variances assumed" row in Table 7 was decided against because the probability of the F-value reported for the Levene's test for equality of variances was 0.012 , which is below the threshold of 0.05 . Therefore, the study did not assume equal variances because the condition for homogeneity of variance was not satisfied, which made it necessary to apply the "equal variances not assumed" row when it comes to the examination of the stated hypothesis.

\section{CONCLUSION AND RECOMMENDATIONS}

The study concludes that the marketing of plantains and bananas in the study area is exclusively dominated by females. It finds that the marketing of the products is profitable. Additionally, it was established that the difference between the profit made by the plantain and banana marketers in the study area is statistically significant.

The study makes the following recommendations based on the findings gathered:

i. Unemployed youths in Rivers State should be trained by well-meaning organisations so that they can take up the marketing of plantains/bananas as a means of earning a living due to their profitability.

ii. To avoid a situation where banana marketers could leave the trade in favour of plantain marketing due to its higher profit, the government should identify and resolve prospective challenges affecting the profitability of banana marketing.

\section{REFERENCES}

Achike, A.I., Okoroafo, U.U., Mkpado, M. (2011). Community empowerment via economic and technical assistance with hybrid plantain/banana enterprise expansion 
programme in Rivers State, Nigeria. Agr.-Sci. J. Tropic. Agric. Food Env. Extens., 10(2), 35-41.

Adetunji, M.O., Adesiyan, I.O. (2008). Economic analysis of plantain marketing in Akinyele Local Government Area in Oyo State, Nigeria. Int. J. Agric. Econ. Rural Dev., 1(1), $15-21$.

Agbugba, I.K. (2020). Economic Analysis of Plantain and Banana Marketing In Etche Local Government Area of Rivers State, Nigeria. J. Ins. Nutr. Metab., 4(2), 5.

Agbugba, I.I. Agbagwa, S.K., Diabate, Y. (2020). SocioEconomic and Profitability Analysis of Honey Marketing in Port Harcourt City Local Government Area of Rivers State, Nigeria. J. Econ. Sust. Dev., 11(6), 1-8.

Aina, O.S., Ajijola, S., Bappah, M.T., Ibrahim, I., Musa, I.A. (2012). Economic Analysis of Plantain Marketing in Odigbo Local Government Area of Ondo State, Nigeria. Glob. Adv. Res. J. Agric. Sci., 1(5), 104-109.

Akinyemi, S.O.S., Adejoro, M.A., Layade, A.A., Adegbite, O.O. (2017). Market Structure and Performance for Plantain and Banana. Int. J. Fruit Sci., 17(4), 440-450.

Ben-Chendo, G.N., Eze, C.C., Asiabaka, C.C. (2013). Value addition to plantain by Women entrepreneurs in Imo State, Nigeria. Dev. Country Studies. 3(10),130-138.

EPAR (Evans School of Policy Analysis and Research). (2013). Banana and plantain value chain: West Africa. EPAR Brief No. 239.

Eronmwon, I., Alufohai, G.O., Ada-Okungbowa, C.I. (2014). Structure, conduct \& performance of Plantain Marketing in Edo State, Nigeria. J. Appl. Sci. Env. Manag., 18(3), $437-440$

Kainga, P.E., Seiyabo, I.T. (2012). Economics of plantain production in Yenagoa local government area of Bayelsa State. J. Agr. Soc. Res., 12(1), 114-123.
Mayokun, K.A., Fisayo, T.A. (2010). Factors Affecting the Improved Technologies in Plantain and Banana Cultivation by Farmers in Ondo State. Nig. J. Agric. Exten., $16-20$.

Newilah, G. N., Tchango, T. J., Fokou, E. \& Etoa, F. (2005). Processing and food uses of bananas and plantains. Fruits, $60,245-25$.

NPC (National Population Commission). (2010). Population figures, National Population Commission. Abuja FCT.

Nwaiwu, I.U., Eze, C.C., Amaechi, E.C., Osuagwu, C.O. (2012). Problems and Prospects of Large-scale Plantain Banana (Musa Spp) Production in Abia State, Nigeria. Int. J. Basic Appl. Sci., 1(4), 322-327.

Obetta, A.E., Obetta, K.C., Achike, A.I. (2018). Economic implications of marketing structure of banana and plantain fruits for the development of rural communities in Enugu State, Nigeria. Fin. Forum, 7(1), 1-9.

Oladapo, M.O., Mommoh, S., Yussuf, S., Awoyinka, Y. (2007). Marketing margin and spatial pricing efficiency of pineapple in Nigeria. Asian J. Mktg., 1(1), 14-22.

Olasunkanmi, J.B., Omitoyin, B.O., Ipinmoroti, M.O. (2012). Social structure of fish farmers Osun State, South-Western Nigeria. Biol. Env. Sci. J. Trop., 9(1), 1-10.

Olumba, C.C., Onunka, C.N. (2020). Banana and Plantain in West Africa: Production and Marketing. Afr. J. Food Agric. Nutr. Dev., 20(2), 15474-15489.

Sadiq, M.S., Singh, I.P., Kolo, M.D. (2015). Resource Optimization in Small- Scale Fish Farming in Minna Agricultural Zone of Niger State, Nigeria. Int. J. Inn. Res. Dev., 4(1), $123-128$.

Taleke, A. (2010). Analysis of rice profitability and marketing chain: The case of Fogra Woreda, South Gondar Zone, Am-hara National Regional State, Ethiopia. [MSc thesis]. Haramaya: University of Haramaya, Ethiopia. 